\title{
CONTROL OF ACUTE POLIOMYELITIS BY IMMUNIZATION
}

\author{
By William GunN, M.B., F.R.C.P., D.P.H. \\ Physician, Infectious Diseases Department, Royal Free Hospital, Hampstead, N.W.3
}

\section{Historical Note}

Poliomyelitis now shares with epidemic influenza the place occupied during the rgth century by cholera, smallpox and typhus fever. Recurring yearly in some form in most highly industrialized countries, it may attack the most favoured with devastating effect, killing approximately ro per cent. and maiming permanently a further 15 per cent. of those attacked. On the other hand, primitive, overcrowded, povertystricken regions generally escape these visitations, due almost certainly to universal infection in childhood. The successful reproduction of the disease in higher apes and proof of its virus nature by Landsteiner and Popper in 1908, and the demonstration of the mode of spread and invasion of its natural hosts by Flexner and Lewis in Igro raised expectations that potent antisera and immunizing antigens would shortly be available. Convalescent serum was first used in Sweden in 2925 (Davide, 1928) and McNamara in Australia (I935) administered it intrathecally and/or intravenously in an endeavour to ward off, or prevent extension of paralysis. None of these measures met with conspicuous success and indeed I.M. and I.T. injections may conceivably conduce to paralysis in cases which otherwise would have remained aparalytic.

The first attempts at active immunization (Brodie in 1934-5, using a suspension of infected monkey spinal cord inactivated by formalin; Kolmer and Rule in 1934, using live virus attenuated by sodium ricinoleate) swiftly ended in disaster; although only a few thousand subjects were inoculated a dozen paralytic cases, some fatal, were encountered 6 to I4 days afterwards. A warning of the danger of these vaccines, issued by the United States Public Health Service (Leake, r935), led to their disuse. In recent years the discovery (Enders et al., 1949) that the Lansing strain could be grown in human embryo tissues and later other strains, in simian renal and testicular tissues ( $\mathrm{Li}$ and Schaeffer, 1953) and the demonstration of the existence of different virus types each with distinctive immunological characteristics (Morgan r948; Bodian et al., r949; Committee on typing I95 I, I953), opened the way to the preparation of a safe, efficient, multivalent vaccine suitable fo general issue and later for commercial productionit But the early expectations of success, widel publicized in the lay and medical press, have proved far from being fulfilled and a re-assessment of the position is now being made at numerous research centres in U.S.A. and other countries including Great Britain.

\section{Passive Immunization by Immune Serum}

Following the successful use of convalescent serum in measles prophylaxis and to a less extenct in rubella and mumps, it was natural to expect similar results against poliomyelitis. In actes trials these proved disappointing, partly ox account of the low antibody levels encountered, in many poliomyelitis convalescents quite ofte lower than in contacts, and partly due to the existence of different immunological virus typeब (three so far identified) and even within these types, of strains which may possess distinctive antigenie characteristics. The occasional occurrence of hepatitis, generally mild in adults but severe an even fatal in children, following administration of human serum whether from recent convalescen donors or normal adults, occasionally even whei irradiated, led to its disrepute. Fortunately the gamma globulin fraction of serum or plasms obtained by means of precipitation by alcohol or ether at low temperatures, according to the teche nique introduced by Cohn and his co-workers in. $194 \mathrm{I}$, is virtually free from this hazard, presumably due to its twenty-fold antibody concentration compared with the parent serum. This preparation has actually been used with success in prophylaxis against infectious hepatitis as well as measles whooping cough and similar diseases of childhood to which adults are commonly immune. Althoug communal immunity to poliomyelitis varies widely in different countries and even in different regions and social classes of the same country, experience 
has shown that provided the plasma pool of donors is large enough (100,000 or so) a reasonably satisfactory titre can be expected. Before issue for poliomyelitis prophylaxis each batch or lot should be tested against a standard sample which has already proved its worth in field trials. Experimental work with susceptible monkeys has shown that if the serum is given with, or before, inoculation or ingestion of the virus, invasion is prevented but not infection, i.e., a symptomless carrier state is the expected sequel. The expense and scarcity of the product at the present time forbid any attempt at mass immunization even in face of a widespread, virulent epidemic; besides there are inherent limitations to its practical application, (I) the absence of a test of individual nonimmunity; (2) the difficulty of ascertaining which contacts are actually infected; (3) the short duration of the protection afforded by a single dose; (4) the probability of re-exposure during a period of epidemic prevalence and hence the possible need for re-injection.

Despite these obstacles, a controlled field study was conducted in U.S.A. in $195^{1}$ and $195^{2}$, involving some 55,000 children, aged I to I I years, half of whom were given $0.14 \mathrm{ml}$. gamma globulin per lb. body weight and half an equal volume of a dilute gelatin solution which so resembled the prophylactic in appearance that neither clinicians nor recipients knew which preparation was administered. Children of similar ages who received no injections were observed over the same period and subsequently used as a control group although these were in some respects not strictly comparable. The analysis of the results (Hammon et al., 1953) revealed significant protection among the test individuals, lasting some $2 \mathrm{I}$ days (corresponding to the half life of the gamma globulin injected), compared with the two control groups; by doubling the dose or using a preparation twice as potent, the period of protection would theoretically be extended by another $2 \mathrm{I}$ days, but this assumption was not put to proof. Since the discovery (McCloskey, I950; Geffen, 1950) that intramuscular inoculations, especially of irritating substances, favour production of paralysis in the limb injected, most severe in, or even limited to, the muscle or part of muscle traumatized, the use of control inoculations can no longer be countenanced even in the interests of science. When exposure can reasonably be presumed the subcutaneous route is preferable although absorption is slower and probably less complete.

Despite these hazards the Ministry of Health issued in 1954 a short memorandum on the prevention of poliomyelitis which incorporated a section on the use of gamma globulin, specifying the centres where stocks are maintained in this country. The recommended priorities and dosage schedules were:

(I) Babies exposed intimately in maternity wards or at home, $5 \mathrm{ml}$. (I ampoule).

(2) Hospitalized children, especially after recent tonsillectomy ( $\mathrm{I}$ to 7 years), $10 \mathrm{ml}$.

(3) Nurses and medical students presumed to be encountering poliomyelitis for the first time, I $5 \mathrm{ml}$.

If taken literally the last-named category would consume all available stocks in a few days as few hospitals do not admit the disease inadvertently, usually in the earliest and most infectious stage, during periods of epidemic prevalence. As a matter of experience, if reasonably careful precautions are taken in respect of a suspected case before transfer to an isolation unit or fever hospital, the staff do not ordinarily require specific prophylaxis. Although poliomyelitis in early pregnancy has not been observed to cause foetal defects, immune serum is justified for contacts near the end of pregnancy as labour complicating paralytic poliomyelitis or vice versa: significantly worsens the prognosis. Familial contacts should also receive high priority, even in young adults if they had recently had an operation. to the buccal cavity, including tooth extraction. As regards dosage, closer adjustment to body weight is advisable than the three scales specified in the memorandum, an easy task if more than one individual is inoculated at the same time.

\section{Therapeutic Serum to Advert Paralysis}

Recent experimental studies by Bodian (1953) have confirmed that potent gamma globulin will avert paralysis in animals already infected, and naturally roused hopes that intravenous administration of adequate amounts, say ro to $20 \mathrm{ml}$. for children and 50 to $100 \mathrm{ml}$. for adults, may avert paralysis if given in the viraemic and even in the meningitic, pre-paralytic stage. But it is probable that when meningitis is present the full viral assault has already taken place, paralysis only appearing in a given area when over one-third of the motor neurones have been destroyed. Further spread of paralysis is usually attributed to secondary changes, notably oedema in the cord, and possibly also in the muscles. A serious difficulty in connection with intravenous gamma globulin is that severe, rarely fatal, reactions have been encountered, presumably due to the ' denatured' state of the molecules following the fractionation process. For this reason concentrated plasma ( 3 to 4 fold) is usually preferred when oedema, especially cerebral oedema, is. considered a factor influencing the prognosis. 
Active Immunization

\section{Inoculation with Formalin-inactivated Virus}

As in 1934, two rival vaccines now hold the field in U.S.A. and once again the formalinized preparation, developed largely by Salk at Pittsburg University, appeared first on the scene and received widespread acceptance, despite the fact that, in the interval, the principle of employing live virus for immunization had been well established. Cox (1954) has listed $\mathrm{I}_{3}$ kinds of vaccine in which virus are being used in attenuated form in human and veterinary prophylaxis. However, poliomyelitis virus stands in a class by itself by reason of its known mutational unpredictability, a circumstance closely associated with high potential virulence to human susceptibles. Early in 1953 Salk reported success in some 600 children $(474$ between 4 and 12 years) with a trivalent vaccine, none developing poliomyelitis during the following period of epidemic prevalence although seven were intimately exposed and three showed afterwards demonstrable serum antibody increases, presumably as a result of the exposure.

Preparation of Vaccine. In the endeavour to render the vaccine innocuous without impairing its immunizing properties, Salk treated virus tissue culture fluid (using monkey kidneys) with 0.4 per cent. formalin ( 37 per cent. formaldehyde) in a bath of melting ice $\left(\mathrm{I}^{\circ} \mathrm{C}\right.$.) for ten days. It was found that while Type 3 strains were sensitive to the chemical, Types 2 (M.E.F.-I) and Type I (Mahoney) were more resistant in that order. These differences may be due to different concentrations of virus rather than to inherent resistance to formalin. The vaccine was then emulsified with a purified mineral oil and emulsifying agent and passed through a Seitz filter to eliminate possible bacterial contamination, and as an additional precaution merthiolate in a concentration of $I: 10,000$ was added as an antiseptic. Tests in monkeys as well as human subjects indicated that the intramuscular route was clearly the most efficient. Aqueous solutions which permitted intradermal inoculation only produced significant antibody against Type 2 strains. Three injections were recommended; in his latest communication Salk (1955) advocated that an interval of two weeks should separate the first two injections (each I ml.), the third (' booster') dose given as long afterwards as practicable, preferably seven to eight months, provided it antedates the next period of epidemic prevalence.

In the autumn of 1953 , the Medical Advisory Committee of the National Foundation for Infantile Paralysis recommended planned extensive trials of the vaccine which were commenced in April 1954, with the assistance of six major commercial manufacturers of biological products.
The results of the inoculations, evaluated by Francien and his team of the Department of Epidemiologyo and the Virus Laboratory, University of Michigan, were announced on April 12, and published in May 1955. Altogether $1,080,680$ children formed the vaccine group and 749,236 the placebo (i.e. received injections without antigen but ignorant? of contents) or control group. Children os similar age living in the same area but not neces 흘. sarily of the same socio-economic class whos received no injections were observed and placed in a third group for comparative purposes as intramuscular injections of any kind are known to predispose to paralytic poliomyelitis. The incidence of paralytic poliomyelitis in the three groups over the period of observation may be simply expressed in the form of a ratio, viz 8 I ; $3.5 ; 3.3$, respectively. Immediately the Francis report was presented licences were్ granted to six commercial firms to release vaccinew without restriction but in the last week of Aprib cases of paralytic poliomyelitis were reported to occur shortly after the injections, at first fromf Cutter preparations (issues suspended on April $277^{\circ}$ and later from those of other firms (all inoculations suspended on May 7); towards the end of the month some batches were released after further testing and administered on a 'voluntary' basis $\overrightarrow{0}$ Finally, a permanent Technical Committee une government control was set up to recommend action on standards and supervise testing vaccine batches (lots) and inoculation was gradually resumed in different states. The्ष general ' all clear' was given in a televisioro programme in which the new Secretary for Health Education and Welfare appeared, on September 4 을

Among the numerous objections to the Salk vaccine the most important are:

(I) Although monkey and virus-inhibition on tissue culture tests indicate that the vaccine is free from risk, these are not necessarily applicable tohumans who are known to be more susceptible to. the virus.

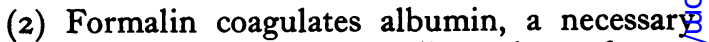
ingredient of tissue culture media, and may form $\$$ protective covering to the dormant virus.

(3) Monkey renal tissue may induce dangerous allergic reactions in human organs especiall $\overline{\mathrm{X}}$ if injections are repeated.

(4) The Mahoney strain, which is known to cause severe paralysis, was unjustifiably incord్టు porated in the vaccine.

(5) The use of penicillin and streptomycin to obviate bacterial contamination in tissue cultures may induce allergic reactions in sensitized subjects?

(6) No evidence is available regarding the duration of the immunity conferred.

That these criticisms were not without founda 8 
tion are confirmed by subsequent investigations and recommendations;

(a) Salk (1955) disclosed that the 1953 vaccine was found to be less potent antigenically in 1954 and recommended the addition of edathamil to thimerosal (merthiolate) to act as a stabilizing agent.

(b) The amended standards officially issued on May I3, were that one litre of vaccine should contain 5 (or more) virus particles (or particulates) less than once in 100,000 times (Scheele and Shannon, 1955), tacitly admitting that it may be impossible to kill all living virus.

(c) The use of the Brunhilde strain was recommended in the vaccine in substitution of the highly virulent Mahoney strain (both belong to Type I).

(d) As the consensus of scientific opinion was that formalin did not necessarily kill all virus, and the immunization mechanism probably depended on the presence of living virus, it appeared that some risk in connection with the Salk vaccine was inevitable; but as no alternative was available, it was considered justifiable to continue its use in regions where poliomyelitis remained a serious problem.

Support for the Salk-type vaccine was provided by the Canadian experience (vaccine produced under stringent conditions in the Connaught Laboratories, Toronto) in which no untoward effects were encountered amongst 400,000 children inoculated; protection appeared adequate, judging by the subsequent attack rate although probably the hazard of exposure is less in its scattered population than in U.S.A. In Denmark where the Brunhilde strain was incorporated in the vaccine in place of the Mahoney strain, no untoward effects had been experienced.

The present position is illustrated by the conclusions at two recent conferences on poliomyelitis.

(I) Meeting of American Public Health Association at Kansas City, Mo.; the vaccine is now safe and one injection is as effective as were three in the previous year; preliminary results from II States showed the attack-rates to be two to five times greater in unvaccinated children (Times, November 16 ).

(2) W.H.O. Conference at Stockholm; since the new regulations came into force in U.S.A. there were no proved instances of harmful effects from the vaccine although a potential risk was admitted. In South Africa I 5,000 children had been inoculated and in Western Germany 100,000, in both instances without ill effects and apparently with protection, but immunization was suspended pending the application of further safety tests. In Great Britain vaccines made by Glaxo Laboratories, Ltd. and the Wellcome Research Foundation, were to be used in the autumn of 1955, but deferred in the light of American experience until the Spring of 1956 , when a safer vaccine will be available. Whether it will be as effective remains to be seen. Some workers consider that use of human amniotic tissue or the growing chick embryo may eliminate all risk provided virus strains can be adapted without antigenic loss (Times, November 27).

\section{Ingestion of Live Attenuated Virus}

Advocacy of living virus as the most effective antigen for active immunization has come mainly from Sabin (1953) and Koprowski (1955). The advantages and objections of this method are obvious but the former undoubtedly outweigh the latter if the risk of mutational reversion to a virulent state could be eliminated. So far the problems connected with this essential condition have not been satisfactorily solved. The suggestion that gamma globulin might be given at the same time to neutralize residual or potential paralyticogenic activity in attenuated virus, quite apart from involving an injection which the ingestion method primarily seeks to obviate, is pointless as long as this reagent is costly and scarce. There remains the possibility that a new strain or type may emerge, which would not be neutralized by gamma globulin until a sufficient number of suitable donors were immunized, either artificially or by natural disease, to provide the immune plasma from which gamma globulin is extracted.

Despite all the difficulties, the scientific and organizational climate remains hopeful that poliomyelitis can be outlawed as completely as diphtheria, although early optimism has been dampened by recent setbacks.

\section{BIBLIOGRAPHY}

BODIAN, D., MORGAN, I. M. and HOWE, H. A. (1949), Amer. F. Hyg., 49, 234 .

BODIAN, D., MORGAN, I. M. and HOWE, H. A. (1953), Ibid.. 58, $8 \mathrm{I}$.

BRODIE, M. (1934), Proc. Soc. Exp. Biol. and Med., 32, 300.

COHN, E. J. (194I), Chem. Rev., 28, 395.

COX, H. R. (1954), Brit. med. F., ii, 259.

DAVIDE, M. (I928), Bull. Off. int. Hyg. publ., $20,74$.

ENDERS, J. F., WELLER, T. H. and ROBBINS, F. C. (1949), Science, ro9, 85 .

FLEXNER, S. and LEWIS, P. A. (1910), F. Amer. med. Ass., 54 1780.

FRANCIS, T. et al. (1953), Amer. F. Pub. Hlth., 45, I.

FRANCIS, T. et al. (1955),' $\mathcal{F}$. Amer. med. Ass., 158, 1266.

GEFFEN, D. (1950), Med. offr., 83, 137.

HAMMON, W. McD. et al. (1953), $\mathcal{F}$. Amer. med. Ass., 151, 1272. KOLMER, J. A. and RULE, A. M. (I934), F. Immunol., 26, 505. KOPROWSKI, H. (I955), 'Poliomyelitis,' W.H.O.,' Geneva, p. 335 .

and POPPER, E. (1908), Wein. Klin. Wschr., LEAK, I830. P. (1935), F. Amer. med. Ass., 105, 2152.

LI, C. P. and SCHÁFFER, M. (1953), Proc. Soc. exp. Biol., N.Y., 82, 477.

Bibliography continued on page $\mathrm{r} 85$ 
BAY, E. B., WRIGHT, R. A., JONES, R. J., PAGE, R. G. and SEIDE, M. (I954), Circulation, 9, 74I.

BEAUMONT, J. L CAEN, J. and BERNARD, J. (1954), in 'Fifth International Congress of Haematology,' Sorbonne, Paris, September 6-12, p. 165, quoted by Pitney and Dacie (I955).

BEAUMONT, J. L., SCEBAT, L. and LENEGRE, J. (1954a), Semaine hop. Paris, 30, 3467.

BILLINGS, F. T., Jnr., KALSTONE, B. M., SPENCER, J. L., BALL, C. O. T. and MENEELY, G. R. (1949), Amer. F. Med., $7,356$.

BINDER, M. J., KALMANSON, G. M., DRENICK, E. J. and ROSOVE, L. (1953), Ұ. Amer. med. Ass., I5I, 967.

BLAND E. F and WHITE, P. D. (194I), Ibid., II7, II7.

BLAUSTEIN, A. U., CROCE, J. J., Jnr., ALBERIAN, M. and RICHEY, N. (1950), Circulation, $x, 1195$.

BOURGAIN, R., TODD, M., HERZIG, L. and WRIGHT, I. S. (1954), Ibid., 10, 680.

BRUETCH, W. L. (1955), Ibid., 11, 909.

BURT, C. C., WRIGHT, H. P. and KUBIK, M. (1949), Brit. med. F., ii, 1250 .

BURT C C ( national Conference on 'Thrombosis and Embolism,' Basle, July 20-24, 1954, Schwabe, Basle.

CANNON, W. B. and MENDENHALL, W. L. (r9r4), Am. $\mathscr{F}$. Physiol., 34, 25x.

CANNON, W. B. (1929), 'Bodily changes in pain, hunger, fear and rage' second edition, Philadelphia, Appleton.

CHANDLER, H. L. and MÁNN, G. V. (I953), New Eng. F. Med.,

CLATANOFF, D. V., TRIGGS, P. O. and MEYER, O. O. (1954), Arch. Int. Med., 94, 213.

CORNELL CONFERENCE ON THERAPY (1954), Am. f. Med., r7, 722.

COSGRIFF, S. W. (1950), F. Amer. med. Ass., 143, 870

COSGRIFF', S. W. (1953), Ann. Int. Med., 38, 278

CRAWFORD, T. and LEVENE, C. I.'(1952), f. Path. Bact.,

CRAWFORD, 523 . T. and LEVENE, C. I. (1953), Ibid., 66, 19.

CULLEN, C. F. and SWANK, R. L. (I954), Circulation, $9,335$. E. F. and WHITE, P. D. (1951), Amer. Heart f., 42, 566.

DE GRAFF, A. C. and LINGG, C. (1935), Ibid, Io, 630. WALKER, W. and WHITTON, I. (1954), Brit. med. $\mathscr{f}$., ii, $96 \mathrm{I}$.

DOUGLAS, A. S. (1955), Brit. Med. Bull., II, 39.

DUGUID, J. B. (1946), f. Path. Bact., 58, 207.

DUGUID, J. B. (1948), Ibid., 60, 57.

DUGUID, J. B. (1949), Lancet, ii, 925

DUGUID, J. B. (1952), Ibid., ii, 207

DUGUID, J. B. (1954), Ibid., i, 891 .

DUGUID, J. B. (1955), Brit. Med. Bull., r1, 36.

ENGELBERG, H. (1952), Amer. F. Med. Sci., 224, 487.

ENGELBERG, $H$. and MASSEL, T. B. (1953), Ibid., 225, 14

ENGELBERG, H. (1954), Surgery, 36, 762.

ENGELBERG, H., KUHN, R. and STEINMAN, M. (1955) Circulation, 12, 497 (Abstract), 'Proceedings of Ninth Annual Meeting of American Society for Study of Arteriosclerosis, Chicago, November 5-6, 1955 .

EVANS, W. (1054), Proc. Roy. Soc. Med., 47, 318.

FIELD, J. B., GOLDFARB, M. S., WARE, A. G. and GRIFFITH, G. C. (1955), Circulation, II, 576.

FISHER, R. L. and ZUKERMAN, M. (1946), f. Amer. med. Ass., I3I, 385. T. and WRIGHT, I. S. (1949), Amer. F. Med. Sci.,

FOLEY, W. T., MC DEVITT, E., SYMONS, C. and WRIGHT,

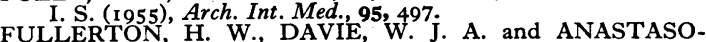
POULOS, G. (1953), Brit. med. $\mathscr{F}$., ii, 250

FULLERTON, H. W. (I955), Proc. Roy. Soc. Med., 48, 664.

GOFMAN, J. W., JONES, H. B., LINDGREN, F. T., LYON, T. P., ELLIOTT, H. A. and STRISOWER, B. (I950), Circulation, 2, 16r.

GOLDBERG, B. and SUZMAN, M. M. (1953), South African Med. Ұ., 27, 389.

GRAHAM," D. M., LYON, T. P., GOFMAN, J. W., JONES, H. B., YANKLEY, A., SIMONTON, J. and WHITE, $S$ (1951), Circulation, 4, 666 .

GRUNER, A., HILDEN, T., RAASCHOU, F. and VOGELIUS, H. (1953), Amer. F. Med., 14, 433.

HAHN, P. F. (1943), Science, 98, 19.
HANSON, H. H., BARKER, N. W. and MANN, F. D. (195I), Circulation, 4, 844 .

HARRISON, C. V. (I948), F. Path. Bact., 60, 289.

HEARD, B. E. (1952), Ibid., 64, 13

HELLEM, A. J. (1943), Nordisk. Medisin., 48, 1558.

HINES, E. A., Jnr. and BARKER, N. W. (1949), Med. Clinics N. Amer., 33, 335.

HUNTER, R. B. and WALKER, W. (1954), Brit. med. f., ii, 197. HURWITZ, A., YESNER, R. and COOKE, R. W. (I952),

Laboratory Investigation, $\mathbf{x}, 436$.
JEWELL, P., PILKINGTON, T. and ROBINSON, B. (1954),

KATZ, L. N., M., i, ror 3.

KATZ, R., DUCCI, H., ROESCHMANN, W. and TORIELLO, L. (1954), Circulation, ro, 685.

KEYES, J. W., DRAKE, E. H., JAMES, T. N. and SMITH, F. J. (1953), Amer. F. Med. Sci., 226, 607.

KUO, P. T. and JOYNER, C.' R. (I955), Circulation, 12, 735.

LUND, E. (1953), Acta. Med. Scandinav., 146, 252.

MACHT, D. I. (I952), f. Amer. med. Ass., 148, 265

MANCHESTER, B. and RABKIN, B. (1954), Circulation, 10, $69 \mathrm{r}$.

MARTORELL, F. (1955), Angiology, 6, 28.

MC LETCHIE, N. G. B. (1952), Amer. F. Path., 28, 413. (1952), Circulation, 6, 479.
MOLTEN, S. E., VROMAN, L. and VROMAN, G. M. S. (1049), Amer. 尹.' Clin. Path., 19, 814

NICHOL,, E. S. and FASSET T, D. W. (1947), South. Med. F.,

NICHO, 631. E. S. and BORG, J. F. (1950), Circulation, I, 1097.

NICHOL, E. S. (1954), Second World Congress of Cardiology, September $12-17$, Washington, D.C.

NICHOL, E. S., PHILLLIPS, W. C. and JENKINS, V. E. (1954), Med. Clinics. N. Amer., 38, 399.

OLWIN, J. H. (1949), Amer. Ұ. Med. Sci., 217, 427.

OWREN, P. A. (1953), Acta. Med. Scandinav. (Supplement 287), $147,46$.

OWREN, P. A. (1954), Schweiz. Med.W Wschr., 84, 822.

PASCALE, L. R. and OLWIN, J. H. (1954), Circulation, 9, 230. PITNEY, W. R. and DACIE, J. V. (1955), Brit. Med. Bull., II, II PRESTO'N, F. W., O'CONNOR, W. R., THOMPSON, C. E. and CHRISTENSEN, E. N. (1952), Circulation, 6, 515

RICE, R. L., ACKERMAN, J. S. and SAICHEK, R. (1950),

Ann. Int.' Med., 32, 735.
RINZLER, S. H., TRAWELL, J., BAKST, H., BENJAMIN, Z. H., ROSENTHAL, R. L., ROSENFELD, S.' and HIRSCH, B. B.' (1953), Amer. F. Med., 14, 438.

RUSSEK, H. I., URBACH, K. F. and DOERNER, A. A. (1952), 7. Amer. med. Ass., 149, 1008.

SCARRONE, L. A., BECK, D. F. and WRIGHT, I. S. (1952), Circulation, 6, 480

SCHNEIDER, R. A. (1951), Amer. F. Med. Sci., 222, 562.

SCHNEIDER, R. A. and ZANGARI, V. W. (r95I), Psychosomatic Medicine, 13, 289 .

SCOTT, R. A. M. and LISSEMORE, N. (1944), Lancet, ii, 405.

SCOTT, R. A. M. (1952), Ibid., i, 488.

SHAPIRO, S. (1953), Angiology, 4,380 .

SISE, H. S. (1954), New England Cardiovascular Society, November 15, Boston, Mass.

SISE, H. S. (1955), Proc. Soc. Exp. Biol. Med., 89, $8 \mathrm{I}$.

SPRAGUE, H. B. and JACOBSEN, R. P. (1948), Med. Clinics of

STEIN, H. B. and WALLACE, B. V. (1952), South African Med. F.,

SUZMAN, M. M., RUSKIN, H. D. and GOLDBERG, B. (1955), Circulation, 12, 338 .

SUZMAN, M. M., (1955), Unpublished data.

SWANK, R. L. (195I), Amer. Ұ. Physiol., 164, 798.

SWANK, R. L. (1954), Science, 120, 427.

TOOHEY, M. (1953), Brit. med. Ұ., i, 650 .

TUDHOPE, G. R. and DONALD, A. C. (1954), Lancet, ii, 465.

TULLOCH, J. A. and GILCHRIST, A. R. (I95I), Amer. Heart $\mathcal{F}$. 42,864 .

TULLOCH, J. and WRIGHT, I. S. (1954), Circulation, 9, 823.

WALDRON, J. M. and DUNCAN, G. G. (1954), Amer. F. Med., I7, 365 .

WEISS, S. and DAVIS, D. (1933), Amer. Heart F., 9, 45.

WESSLER, S. (1953), $\mathcal{F}$. Clin. Investigation, 32, 650 .

WESSLER, S. and MORRIS, L. E. (1955), Circulation, 12, 553.

WOOD, J. C. and CONN, H. L., Jnr. (1954), Ibid., ro, 517

WRIGHT, I. S. and FOLEY, W. T. (I947), Amer. F. Med., 3. i 18.

Bibliography continued from page r77-William Gunn, M.B., F.R.C.P., D.P.H.

McCLOSKEY, B. P. (1950), Lancet, i, 159.

MACNAMARA. J. (1935), Med. F. Austral., 2, 374.

MORGAN, I. M. (I948), Amer. F. Hyg., 48, 394

MORGAN, I. M. (I 948), Amer. F. Hyg., 48, 394 mittee on typing,

I95 $\mathrm{I}$, Ibid., 54, I9I.
National Foundation for Infantile Paralysis, Committee on typing, $195 \mathrm{I}$, Ibid. (1953), 58, 74 .
SABIN, A. B. (1955), Amer. F. Dis. child., 86, 301.

SALK, J. E. et al. (1953), F. Amer. med. Ass., 151, ro8 r.

SALK, J. E. et al. (1954), Amer. F. Pub. Hlth., 44, 563.

SALK, J. E. et al. (1955), F. Amer. med. Ass., 158, 1239.

SCHEELE, L. A. and SHANNON, J. A. (1955), Ibid., 158, 1249. 